\title{
BIOCHEMICAL AND BIOLOGICAL EFFECTS OF INSECT GROWTH REGULATOR, TEFLUBENZURON ON PECTINOPHORA GOSSYPIELLA (SAUNDERS) (LEPIDOPTERA: GELECHIIDAE) AND COCCINELLA UNDECIMPUNCTATA (L.) (COLEOPTERA: COCCINELLIDAE)
}

\author{
Saadiya M. Said ${ }^{(1)}$, A. M. Abd El-Raheem ${ }^{(1)}$ and Mervat A. Kandel ${ }^{(2)}$ \\ (1) Economic Entomology \& Agricultural Zoology Dept., Faculty of Agriculture, Menoufia \\ University, Menoufia, Egypt. \\ (2) Plant Protection Research Institute, Agriculture Research Center, Dokki - Giza,
}

Received: Feb. 21, 2017

Accepted: Mar. 1, 2017

\begin{abstract}
This work was conducted to study the effects of the insect growth regulator, Teflubenzuron on survival, reproduction parameters of Pectinophora gossypiella, (Saunders) (Lepidoptera: Gelechiidae) as well as on pupae and adults of Coccinella undecimpunctata (L.) (Coleoptera: Coccinellidae). As for P. gossypiella the $L C_{25}$ and $L C_{50}$ values were 19.36 and 78.59 ppm, respectively, when the newly hatched larvae treated by Teflubenzuron, while $L C_{90}$ value was $1189.25 \mathrm{ppm}$. Teflubenzuron treatments significantly prolonged the developmental time of survived larvae and pupae, causing longer life span compared to control. Statistical analysis of the obtained data demonstrated highly significant differences between oviposition and reproductive adults resulted from treated larvae and the control. The treatment with $L C_{50}$ (78.59 ppm) of Teflubenzuron reduced the total protein content, while the phenoloxidase content was high significantly decreased. Chitinase activity was significantly increased causing failure of the pupation process. The transaminase enzymes activity (Got and GPT) were highly increased. Regarding to C. undecimpunctata, there were different mortality percentages of pupal after one to 7 days of exposing to 300, 150, 75, 37.5, 18.75 and 9.375 ppm of Teflubenzuron, where mortality and malformed was increased by increasing Teflubenzuron doses. Furthermore, pupa duration of the predator was significantly prolonged by increasing IGR doses, while adult longevity and fecundity were significantly decreased. Total protein and phenoloxidase values were significantly reduced when the pupal stages were treated and adult fed on $P$. gossypiella eggs treated with $L C_{50}$ of Teflubenzuron.
\end{abstract}

Key words: IGR, Control, Chitinase, protein, transaminase, phenoloxidase.

\section{INTRODUCTION}

The pink bollworm (PBW) Pectinophora gossypiella (Saunders) (Lepidoptera: Gelechiidae) is a major cotton pest in different countries and in the Arab republic of Egypt as well. Larvae attack the flower, buds and bolls of cotton causing loss in both quantity and quality of cotton yield (Anonymous, 1996).

The eleven-spot ladybird, Coccinella undecimpunctata (L.) is among the most abundant predators recorded in different crop in all Governorates. They are voracious predators, and combined with their high abundance of pests may play an important role in the reduction of pest populations. Individual of $C$. undecimpunctata lack many of the characteristics suggested (assemblages) as necessary for a successful biological-control agent. They feed on a variety of prey (such as aphid, whitefly, jassid, pink bollworm and other pests). In Egypt agro ecosystems is largely unknown, and do not exhibit densitydependent tracking of prey populations. On the other hand, the use of some chemical during the presence of the predator in the field may be high affected the population, 
biology, fecundity and biochemical content of the predator.

Insect growth regulators (IGR's) is considered as alternative way of synthetic insecticides for controlling Spodoptera littoralis (Raslan, 2002). They disrupt the physiology and development of the target insect. They tend to be selective and less toxic to non-target organisms than other pesticides (Gurr et al., 1999). IGR's had been grouped in chitin synthesis inhibitors (CSIs) and interfere with the action of insect hormones such as juvenile hormone and ecdysteroids (Tunaz and Uygun, 2004). CSIs disrupt chitin biosynthesis (Gijswijt et al., 1979) they prevent molting, and produce an imperfect cuticle (Hammock and Quistad, 1981). Also, they disrupt the hormonal balance (Soltani et al., 1984). These compounds have no effects on parasitoids and other natural enemies (Ishaaya et al., 2002). Also, it has low mammalian toxicity (Barazani, 2001).

A new approach in the insect control is to use substances that affect insect growth and development. These substances are insect growth regulators (IGR) which receiving more practical attention to provide for safe foods and clean environment. The chitin synthesis inhibitor (CSIs) introduce into the market as a novel insecticide named Teflubenzuron (TFB).

Most CSIs are mostly used as larvicides, as treated larvae develop until molting, but fail to molt due to inhibition of the synthesis of new cuticle, specifically, chitin biosynthesis.

For instance: some (IGRs), when directly applied to Manduca epidermal cells in vitro, inhibited endo-cuticular deposition (Miyamoto etal., 1993). Moreover, chitin precursors of Pieris larvae (14C-glucose), Manduca larvae (14 C-glucosamine), Mamestra larvae (14 C-acetylglucosamine) and Spodoptera larvae (14-C-UDP-Nacetyglucosamine) were not incorporated into chitin in the presence of chitin synthesis inhibitors. The role of insect hormones in reproduction has been extensively reviewed (Prabhaker and Toscano, 2007).

From the previous review, the aim of this work is to evaluate the effect of the insect growth regulator Teflubenzuron (TFB) on the pink bollworm (PBW) Pectinophora gossypiella and the eleven-spot ladybird Coccinella undecimpunctata (L.)

\section{MATERIALS AND METHODS Insect growth regulators (IGR) used:}

Common name:Teflubenzuron (benzoylurea) Trade name: Nomolt \& 15\% Suspension Concentrate (SC).

Rate of application: $50 \mathrm{~cm}^{3} / 100 \mathrm{~L}$. Basic product: BASF Co.

\section{Tested insects:}

The susceptible laboratory strain of pink bollworm, $P$. gossypiella was reared for several generations under the laboratory conditions at $26 \pm 1^{\circ} \mathrm{C}$ and $75 \pm 5$ R. $\mathrm{H} \%$ at Bollworms Research Department, Plant Protection Research Institute, Agriculture Research Center, while the eleven-spot ladybird, Coccinella undecimpunctata (L.) predator stages were collected from the experimental farm of faculty of agriculture, Menoufia University at Shebin Elkom, Menoufia Governorate, from cotton field during 2015 season. Different eggs, larvae, pupae and adult stages of the predator were collected by hand and sweeping net and sent to the laboratory for the experiments as field strain.

\section{Determination the toxicity on newly hatched larvae of $P$. gossypiella:}

The toxicity of the tested compound against newly hatched larvae of $\boldsymbol{P}$. gossypiella were studied. Different concentrations of the tested compound were sprayed on the upper surface of $15 \mathrm{~g}$ of artificial diet placed in Petri-dish $(9 \mathrm{~cm}$ in diameter). Six concentrations of tested compound IGR were prepared $(300,150$, 
75, 37.5, 18.75 and 9.375 ppm).

Fourteen newly hatched larvae of the pink bollworm were placed on the surface of the treated diet using a soft brush. Another group of Petri-dishes was prepared containing the same diet and sprayed only with distilled water (used as control) and 60 larvae were placed on their surfaces. (three replicates for each treated and untreated were used) Larvae were allowed to feed on the tested diets for $24 \mathrm{hr}$, and transfer to untreated diet. Afterwards larval mortalities were recorded after $24 \mathrm{hr}, 3$ and 7 days of treatment.

$\mathrm{LC}_{50}$ of newly hatched larvae were calculated, and larvae were allowed to feed on $\mathrm{LC}_{50}$ treated diet (three replicates for each assay). After that, the survivors in each assay were counted and transferred to glass vials $(2 \times 7 \mathrm{~cm})$ containing $3 \mathrm{~g}$ of untreated diet and kept at $26 \pm 1^{\circ} \mathrm{C}$ and $75 \pm 5 \%$ R.H. Larvae of control were fed on untreated diet sprayed only with water instead of tested compound.

Larval mortality, abnormality and different biological effects on the larvae, pupae and adults (moths) were recorded. After moth emergence, three replicates each contained cage of (5-pairs/cage) of emerged moths that appeared morphologically not impaired were used to measure the reproductive potential of the insects in assay. Laid eggs were incubated under controlled conditions then counted after hatching to estimate the egg hatchability percentages.

Reduction in hatchability percentage was calculated according to Zidan and AbdelMegeed (1987). Fecundity percentage was calculated according to Crystal and Lachance (1963) as follows:
The recorded data were statistically analyzed with one - way analysis of variance (ANOVA) $(\mathrm{P}<0.05 \%)$ (Snedecor, 1952) and Duncan's multiple range test of means.

\section{Treating pupal stage of Coccinella undecimpunctata predator:}

The larvae and pupae of $C$. undecimpunctata predator which were collected from the field were reared singly in tubes $\left(7 \times 2.5 \mathrm{~cm}^{2}\right)$. Larvae were fed and daily observed until pupation for used in treatment.

Three replicates each contains 20 pupae (1-2 day old) of $C$. undecimpunctata were sprayed by different concentrations (300, $150,75,37.5,18.75$ and $9.375 \mathrm{ppm}$ ) of the tested compound in Petri-dish, after $1 \mathrm{hr}$, pupae were translated singly in tubes $(7 \mathrm{x}$ $2.5 \mathrm{~cm}^{2}$ ).After that, pupal mortalities (from 10-14 days) and the time of adult emergency were recorded. Percentages of mortalities were corrected according to Abbott's formula (1925).

\section{Feeding the adults of $C$. undecimpunctata:}

Treatment of $P$. gossypiella eggs was done by dipping a piece of paper containing eggs treated with (LC50). Three replicates from eggs were used, (from 200 to 300 eggs on paper for each replicate). After that the papers were left until dried then introduced to $C$. undecimpunctata adults for feeding. Other of similar eggs were dipped in water used as a control. The treated and untreated eggs were offered to adults' predator daily until died.

$$
\begin{aligned}
& \text { no. hatched eggs in check }- \text { no. hatched eggs in treatment } \\
& \text { no. of hatched eggs in check } \\
& \text { no. of eggs / treated female } \\
& \text { no. of eggs / untreated female }
\end{aligned}
$$




\section{Preparation of samples for biochemical assay:}

Samples of Pectinophora gossypiella larvae were collected at 12-14 days after treatment of the newly hatched larvae (during the molting), while, $C$. undecimpunctata pupae and adults were collected at $7-10$ days after treatment with $\mathrm{LC}_{50}$. Untreated larvae of $P$. gossypiella and C. undecimpunctata (pupae and adults) stages were used as control.

\section{Biochemical analyses:}

The total lipids were estimated by the method of Knight et al., (1972), colorimetric determination of total soluble protein in total homogenate $P$. gossypiella larvae was carried out, as described by Bradford (1976). Transaminase enzymes. Aspartate amino transferase (AST) and alanine aminotransferase (ALT) enzyme activities were determined calorimetrically according to the method of Reitman and Frankle (1957). Determination of chitinase activity was prepared according to Bade and Stinson (1981) and the reaction mixture of enzyme assay according to Ishaaya and Swirski (1976). Determination of $\mathrm{N}$-acetylglucosamine by the sensitive method of Waterhouse et al., (1961). Phenoloxidase activity was determined according to modification of Ishaaya (1971) and Total proteins were determined by the method of Bradford (1976).

\section{RESULTS}

Toxicity of Teflubenzuron on newly hatched larvae of $\boldsymbol{P}$. gossypiella:

The $\mathrm{LC}_{25}, \mathrm{LC}_{50}$ and $\mathrm{LC}_{90}$ values of the tested IGR, Teflubenzuron on the newly hatched larvae of $P$. gossypiella were 19.36, 78.59 and 1189.25 ppm, respectively.

Effects of $\mathbf{L C}_{50}$ values of Teflubenzuron on the mortality, development period and fecundity of $P$. gossypiella Larval and pupal stages:

Data in Table (1) reported that the mortality in newly hatched larvae of PBW was gradually increased after 1 to 3 days reaching $59.6 \%$ mortality, compared to $2 \%$ in control and raised to $71.9 \%$ mortality after 1 to 18 days of application compared to $7 \%$ in control,.

\section{Developmental period of larvae and pupal stages:}

Significant differences occurred in the developmental periods of larval \& pupal stages and total life span (from larva to adult stage) and adult fecundity (reproductive) of $P$. gossypiella in treated compared with untreated (Table 1).

Table (1): Effect of LC ${ }_{50}$ value of Teflubenzuron on some biological parameters of $P$. gossypiella larval and pupal stages.

\begin{tabular}{|c|c|c|c|c|c|}
\hline \multirow{2}{*}{ Treatments } & \multicolumn{2}{|c|}{ Mortality larvae \% } & \multicolumn{3}{c|}{ Time in days } \\
\cline { 2 - 6 } & $\begin{array}{c}\mathbf{1 - 3 - 7} \text { days } \\
\text { from } \\
\text { treating }\end{array}$ & $\begin{array}{c}\text { Accumulative } \\
\text { Mortality until } \\
\mathbf{1 8} \text { days }\end{array}$ & $\begin{array}{c}\text { Larval (L) } \\
\text { Duration }\end{array}$ & $\begin{array}{c}\text { Pupa (P.) } \\
\text { duration }\end{array}$ & $\begin{array}{c}\text { Total L \& P } \\
\text { Stags }\end{array}$ \\
\hline LC & $59.6 \pm 3.76$ & $71.9 \pm 3.51 \mathrm{~b}$ & $20.3 \pm 1.51 \mathrm{~b}$ & $10.63 \pm 0.31 \mathrm{~b}$ & $30.93 \pm 2.5$ \\
\hline Untreated & $2.0 \pm 0.58$ & $7.67 \pm 0.88 \mathrm{a}$ & $14.60 \pm 0.35 \mathrm{a}$ & $7.36 \pm 0.3 \mathrm{a}$ & $21.96 \pm 1.3$ \\
\hline LSD 5\% & & 0.254 & 1.665 & 0.306 & 2.331 \\
\hline
\end{tabular}


Data in Table (1) show that Teflubenzuron doses significantly prolonged the developmental period of survived larvae and pupae compared with the control. The treated larval duration averaged to 20.3 days/ larvae and 10.63 days/ pupae compared with 14.6 days/ larvae and 7.36 days/ pupae, respectively, in the untreated control.This period prolonged (approximately from 1.4 time / larvae and 1.6 times/ pupae) when newly hatched larvae treated with the growth inhibitor than control.

In the same table data illustrated significant increased in total immature stages of $P$. gossypiella resulted from the newly hatched larvae treated to 30.93 days compared with 21.96 days in control.

The obtained results supported by Kandel et al., (2013) who recorded that the CSI, compound increased developmental period of $P$. gossypiella larvae and pupae, which led to longest total life span (from larval to adult stage), it estimated by 54.23 days/ life span in treated compared to 42.46 days/ life span in control, in addition treated larvae showed the presence of a double cuticle and could not shed the old cuticle.

\section{Oviposition and reproductive potential:}

Statistical analysis of the data in Table (2) demonstrated that highly significant differences between oviposition and reproductive adults resulted from treated larvae and the control. The mean number of deposited eggs (fecundity) by females emerged from larvae treated with $\mathrm{LC}_{50}$ value of Teflubenzuron were 160.0 eggs/female, compared to 226.67 eggs/ female in untreated control.

These data indicated that the treated larvae by Teflubenzuron caused significantly high reduction in laid eggs by females to $29.4 \%$. At the same trend, the treatment by Teflubenzuron caused high reduction in percentage of hatchability (fertility) reaching 42.7\%compared with 5.4 in control. Similar trend was reported in the larval mortality with the first molting larvae.

\section{Malformation of different stages of pink bollworm and the lady bird:}

As shown in Figure $(1,2)$ the tested IGR, Teflubenzuron caused malformation in all stages of both pink bollworm, P. gossypiella (larvae, pupae and moths) and its predator, C. undecimpunctata, (pupae) which failed to complete their life cycles.

\section{Biochemical studies:}

The most important enzymes which play a key role in molting process in body of $P$. gossypiella were analyzed for their activities i.e. total protein, phenoloxidase, chitinase and $\mathrm{N}$-acetyl glucoseamine, Free-amino acid, Transaminase enzymes, Aspartate aminotransferase (AST) and alanine aminotransferase (ALT).

Table (2): Effect of LC ${ }_{50}$ value of Teflubenzuron on some biological parameters of $P$. gossypiella adult stage.

\begin{tabular}{|c|c|c|c|c|c|c|}
\hline & \multirow{2}{*}{ Treatment } & $\begin{array}{c}\text { Adult } \\
\text { emergency } \\
\%\end{array}$ & $\begin{array}{c}\text { Total } \\
\text { eggs }\end{array}$ & $\begin{array}{c}\text { Hatchability } \\
\%\end{array}$ & $\begin{array}{c}\text { Reduction } \\
\%\end{array}$ & \multicolumn{2}{|c|}{\begin{tabular}{c} 
Time in days \\
\cline { 5 - 7 }
\end{tabular}} & $\begin{array}{c}\text { Longevity } \\
\text { of female }\end{array}$ & $\begin{array}{c}\text { life span } \\
\text { from larvae } \\
\text { to adults }\end{array}$ \\
\hline LC $_{50}$ & $\begin{array}{c}75.33 \\
\pm 5.12\end{array}$ & $\begin{array}{c}160.0 \\
\pm 2.1\end{array}$ & 57.3 & 42.7 & 23.3 & $54.23 \pm 2.1$ \\
\hline Untreated & $\begin{array}{c}95.33 \\
\pm 0.91 \mathrm{~b}\end{array}$ & $\begin{array}{c}226.67 \\
\pm 4.91 \mathrm{~b}\end{array}$ & 94.6 & 5.4 & 18.55 & $42.46 \pm 2.1$ \\
\hline LSD 5\% & 4.225 & 8.215 & 7.335 & 1.422 & 0.025 & 3.208 \\
\hline
\end{tabular}


Said, et al.,

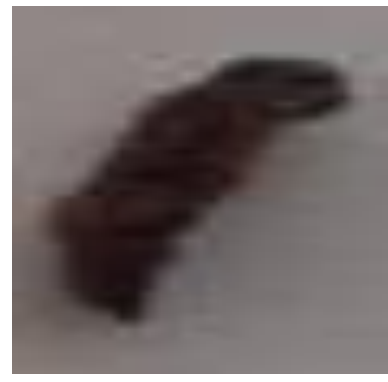

Larva

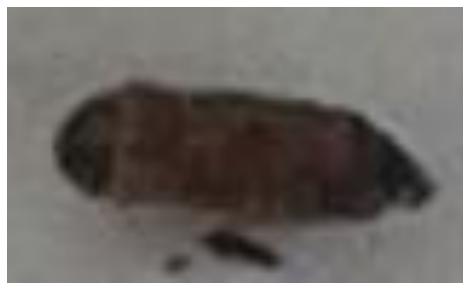

Pupa

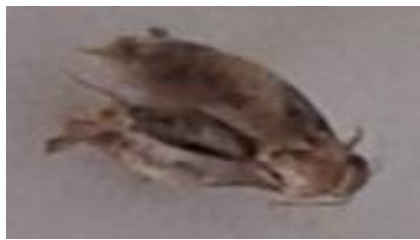

Moth

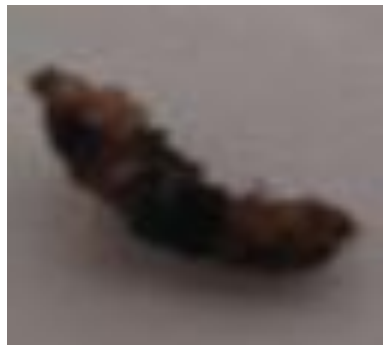

Larva

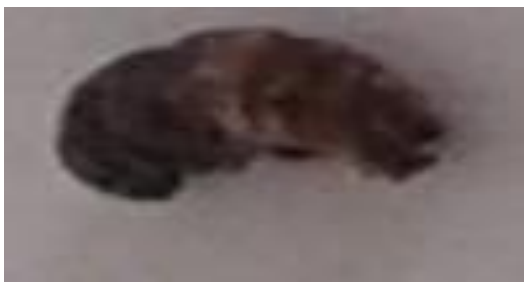

Pupa

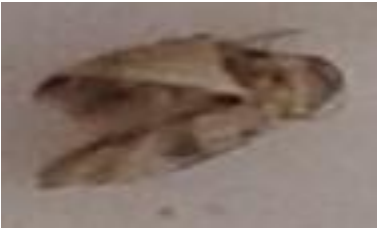

Moth

Figure (1) Malformation in cotton bollworm stages

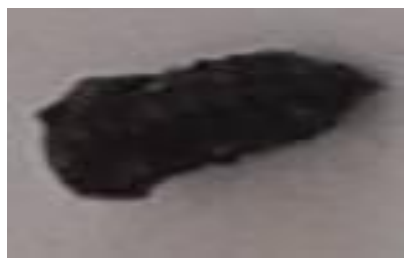

Pupa

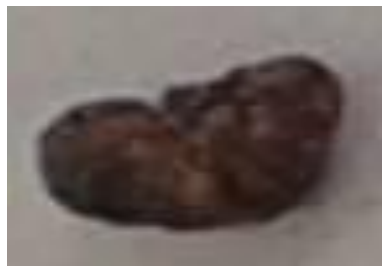

Pupa

Figure (2) Malformation in lady bird pupae 
Results in Table (3) show the effect of Teflubenzuron on some biochemical changes of PBW as the total contents of protein and phenoloxidase when the $1^{\text {st }}$ instars larvae fed on diet treated with $\mathrm{LC}_{50}$ (78.59 ppm) of Teflubenzuron.

The obtained results supported by Nehad M. El-Barkey et al., (2009) who found that the treatment of $P$. gossypiella larvae and pupae with (IGRs) reduced the total protein content to $10.5 \mathrm{mg} . / \mathrm{gb} . \mathrm{wt}$ (approximately $50.1 \%$ ) compared with $21.935 \mathrm{mg} . / \mathrm{gb} . \mathrm{wt}$ in control. Thompson et al., (2005) reported that the reduction in total protein soluble has been found in analyzed larvae to be a key factor for elongated in development immature stages and reduction in number of eggs laid (adults fecundity). Furthermore, Simpson et al., (2004), Raubenheimer and Simpson (2005) found that the ratio of proteins to soluble carbohydrates (P: C) has been necessary for development, or survivorship of some other insect species.

While the phenoloxidase which necessary in melanin production during cuticle content, the obtained results in Table (3) revealed that it decreased to 4.74 (O.D. units/gb.wt) equal to $83.34 \%$ in the treatment, this decrease indicate that the treatment caused reduction in phenoloxidase approximately by 8 times than control.

The obtained results supported by Assar et al., (2016) who found that after treating $S$. littoralis with the IGR, the activity of phenoloxidase was highly significantly decreased.

In addition, data in Table (3) reported that the chitins activity of the larvae treated with Teflubenzuron was 1101.67 compared to1050 in control, while, the units $(\mu \mathrm{g} \mathrm{N}$ acetyl glucoseamine liberated $x 103 / \mathrm{min} / \mathrm{g}$. b.wt.) increased approximately to (2 times), it determined by 289.67 in larvae treated compared to 165.33 in larvae untreated. It could be concluded that Teflubenzuron caused incomplete larval molting and failed pupation.

The obtained results are confirmed with that obtained by Kandel et al., (2013) who explained the effect of (IGRs) on chitin activity in the body of $P$. gossypiella larvae fed on diet treated with $78.59 \mathrm{ppm}$.

Table (3): Some biochemical changes in $P$. gossypiella larvae (during molting process) treated with Teflubenzuron (IGR) at $987.59 \mathrm{ppm}$

\begin{tabular}{|c|c|c|c|}
\hline Biochemical aspects & Treated & Control & $\begin{array}{l}\text { decreased(-)or } \\
\text { increased }(+)\end{array}$ \\
\hline Total protein(mg/g.b.wt) & $10.51 \pm 0.31$ & $21.93 \pm 0.7$ & -52.1 \\
\hline $\begin{array}{l}\text { Free-amino acid( } \mu \mathrm{g} D, \mathrm{~L}- \\
\quad \text { alanine/g.b.wt) }\end{array}$ & $831.17 \pm 20.4$ & $622.3 \pm 11.9$ & +32.44 \\
\hline Phenoloxidase(O.D. units/g.b.wt) & $4.74 \pm 0.23$ & $28.47 \pm 1.6$ & 83.4 \\
\hline $\begin{array}{c}\text { N- acytel-glucceamine( } \mu \text { g NAGA } \\
\text { /g.b.wt) }\end{array}$ & $289.67 \pm 4.69$ & $165.33 \pm 5.7$ & +75.2 \\
\hline $\begin{array}{c}\text { Chitinase } \\
\left(\mu \mathrm{g} \text { NAGA } \times 10^{3} / \mathrm{min} / \mathrm{g} . \text { b.wt }\right)\end{array}$ & $1101.67 \pm 39.39$ & $1050 \pm 16.12$ & +4.92 \\
\hline $\begin{array}{l}\text { Aspartate aminotransferase } \\
\text { (AST) (GOT) (U x } 10^{3} / \text { g.b.wt) }\end{array}$ & $6670 \pm 380.8$ & $663.66 \pm 217.6$ & +905.03 \\
\hline $\begin{array}{c}\text { alanine aminotransferase (ALT)Gpt } \\
\left(\mathrm{U} \times 10^{3} / \text { g.b.wt }\right)\end{array}$ & $1533.3 \pm 34.3$ & $1528.67 \pm 37.7$ & +0.7 \\
\hline
\end{tabular}




\section{Transaminase enzymes (GOT and GPT or ALT and AST):}

Data in Table (3) show the transaminase enzymes activity on larvae of $P$. gossypiella reared on diet treated by $\mathrm{LC}_{50}$ (IGRs). The levels of GOT were highly increased to 6670 compared to $663.66 \mathrm{mg} / \mathrm{ml}$ in control, while, the transaminase enzymes GPT activity on treated PBW larvae was $(1533.3 \mathrm{mg} / \mathrm{ml}$ ) compared with $(1528.67 \mathrm{mg} / \mathrm{ml})$ in untreated.

Toxicity of Teflubenzuron on pupae and adults of $\boldsymbol{C}$. undecimpunctata:

The obtained data in Table (4) revealed that the $\mathrm{LC}_{25}$ and $\mathrm{LC}_{50}$ values were 37.2 and $109.9 \mathrm{ppm}$, respectively when the 1-2day old pupal stage treated by Teflubenzuron, and were 29.6 and 1189.25 ppm for adult stages of lady bird.

\section{Adult mortality and malformed of C. undecimpunctata:}

Data in Table (4) show the percentages of (pupal stages) mortality of $C$. undecimpunctata after using different levels of concentrations $(300,150,75,37.5,18.75$ and $9.375 \mathrm{ppm}$ of Teflubenzuron) at $24 \mathrm{~h}, 7$ and 10 days. The differences among compound levels on pupae mortality rates were statistically significant. The percentages mortality of the predator were higher when the levels of Teflubenzuron
(TFB) increased (Coccinella adult stage; $\mathrm{F}=$ $2115 \mathrm{DF}=5, \mathrm{P}<0.05)$. A total of $66 \%$ pupa stages were died at recommended rate.

Results in table (4) showed the percentage of adults' emergence, the results indicated that percentage of adults emergence decreased by the increasing of used concentration. The vales were $(6.6,20$, $51.66,71.66,38.33,90$ and 93.33 respectively), when $300,150,75,37.5$, 18.75 and 9.375 were used, respectively.

\section{Malformation of lady bird pupae:}

As shown in table, 4 and Figure (2) the tested IGR, Teflubenzuron caused malformation in predator, $C$. undecimpunctata, (pupae) which failed to complete their life cycles. The malformed percentages of the predator were decreased when the levels of (TFB) decreased from (32 to $1 \%$.

\section{Duration of pupal stages:}

Statistical analysis of results in Table (4) revealed that there were highly significant differences between the time periods in day for pupae treatment and untreated. The duration in treatment averaged 14.3 days/ pupa compared with 6.5 days, in the untreated pupae.

Table (4): Effect of different concentration of the tested IGR on toxicity and duration of $C$. undecimpunctata pupae

\begin{tabular}{|c|c|c|c|c|c|}
\hline \multirow[b]{2}{*}{$\begin{array}{l}\text { Conc. } \\
\text { (ppm) }\end{array}$} & \multirow[b]{2}{*}{$\begin{array}{l}\text { number } \\
\text { of pupae }\end{array}$} & \multicolumn{3}{|c|}{ Treated C. undecimpunctata pupae } & \multirow[b]{2}{*}{$\begin{array}{c}\text { \%adults } \\
\text { Emergence }\end{array}$} \\
\hline & & $\begin{array}{l}\text { Mortality \% } \\
\text { ( after } 24 \mathrm{~h} \text { to } \\
10 \text { days) }\end{array}$ & $\begin{array}{c}\text { Malformed } \\
\% \text { ( from7-12 } \\
\text { days) }\end{array}$ & $\begin{array}{c}\text { Duration } \\
\text { (days) }\end{array}$ & \\
\hline 300 & 60 & 61.4 & 32 & - & 6.6 \\
\hline 150 & 60 & 56 & 24 & $16-18$ & 20 \\
\hline 75 & 60 & 37.34 & 11 & $14-17$ & 51.66 \\
\hline 37.5 & 60 & 20.34 & 8 & $13-15$ & 71.66 \\
\hline 18.75 & 60 & 10.67 & 6 & $9-10$ & 83.33 \\
\hline 9.375 & 60 & 9 & 1 & $7-9$ & 90 \\
\hline Control & 30 & 6.67 & - & $6-7$ & 93.33 \\
\hline
\end{tabular}




\section{Effect of IGR on Fecundity and longevity:}

Results in Table (5) indicated that The highest number of eggs (189 eggs/ female) were deposited by Coccinella fed on PBW eggs untreated, while the predator females fed on eggs treated with IGR laid the lowest number of individual eggs (76.6 eggs/ female). The cumulative number of eggs laid per female of lady bird decreased to about $59.4 \%$ compared to control when adult females were treated and feed on eggs treated with recommended dose of the compound. The highest longevity was recorded by adult female fed with the eggs untreated. Teflubenzuron significantly decreased the oviposition period and longevity days for $C$. undecimpunctata females.

The oviposition period of females fed continuously on PBW eggs treated with the recommended $\mathrm{LC}_{50}$ took 24.6 days compared with 37.9 days/ female in control; during this period the number of eggs were sharply decreased to the half compared to control.

Data in Table (6) show the changes in some biochemical analyzes of $C$. undecimpunctata in total protein and phenoloxidase when the pupal stage treated with $\mathrm{LC}_{50}$ of Teflubenzuron.

Treatment with $\mathrm{LC}_{50}$ IGR reduced the total protein content to 6.29 in pupae compared with 8.77 in control and 7.9 in treated adults compared to 13.28 in control, while the phenoloxidase which necessary in melanin production during cuticle composition increased approximately 2 times, it estimated by 9.95 (O.D. units/g b. wt) in treated pupae compared with 5.96 in control.

\section{DISCUSSION \\ Biological aspect:}

Nehad M. El-Barkey et al., (2009) found that Hexaflumuron (IGR) caused a prolongation in larval and pupal developments of $S$. littoralis, where durations were 22.3, 20.6 and 20.4 days, respectively for larvae after egg treated and $10.8,10.0$ and 11.3 days, respectively for pupae. Also, they found high reduction in total laid eggs, percentage of hatchability and longevity in adult stage and low concentration of IGR reduced the fecundity and egg hatching and increased the sterility of adults resulted from treated larval and pupal stages.

Table (5):Effect of Teflubenzuron on soma biological aspects for $C$. undecimpunctata

\begin{tabular}{|c|c|c|c|c|c|}
\hline \multirow{2}{*}{$\begin{array}{c}\left.\text { Conc. (LC }{ }_{50}\right) \\
\text { Ppm }\end{array}$} & \multirow{2}{*}{$\begin{array}{c}\text { Initial } \\
\text { number of } \\
\text { pupa }\end{array}$} & \multicolumn{3}{|c|}{ Treated C. undecimpunctata pupae } & \multirow{2}{*}{$\begin{array}{l}\% \text { adults } \\
\text { emergence }\end{array}$} \\
\hline & & Mortality\% & Malformed\% & Duration & \\
\hline 106.9ppm & 60 & 48 & 32.3 & $14.3 \pm 0.6$ & 67.7 \\
\hline Control & 60 & 3 & 1 & $6.5 \pm 0.2$ & 96 \\
\hline LSD 5\% & - & 0.255 & 0.745 & 1.684 & 3.558 \\
\hline \multicolumn{6}{|c|}{ Adult stage } \\
\hline 冫 & Oviposition & $\begin{array}{l}\text { Total egg/ } \\
\text { female }\end{array}$ & $\begin{array}{l}\text { Reduction in } \\
\text { laid eggs\% }\end{array}$ & $\begin{array}{c}\% \\
\text { hatchability }\end{array}$ & Longevity \\
\hline 106.9ppm & $24.6 \pm 0.3$ & $76.6 \pm 0.3$ & 64.2 & 66 & 37.3 \\
\hline Control & $37.9 \pm 0.3$ & $189 . \pm 0.3$ & - & 89 & 46.5 \\
\hline LSD 5\% & 2.635 & 5.693 & - & 2.112 & 2.441 \\
\hline
\end{tabular}


Said, et al.,

Table (6):Biochemical aspects of $987.59 \mathrm{ppm}$ Teflubenzuron dose on two stages of $C$. undecimpunctata

\begin{tabular}{|c|c|c|c|c|}
\hline \multirow{2}{*}{ Biochemical aspects } & \multicolumn{2}{|c|}{ Pupal stage } & \multicolumn{2}{|c|}{ Adults stage } \\
\hline & Treated & Control & Treated & Control \\
\hline Total protein(mg/g.b.wt) & $6.29 \pm 0.2$ & $8.77 \pm 0.3$ & $7.6 \pm 0.6$ & $13.28 \pm 0.63$ \\
\hline $\begin{array}{l}\text { Free-amino acid( } \mu \mathrm{g} \text { D,L- } \\
\quad \text { alanine/g.b.wt) }\end{array}$ & $721 \pm 15.61$ & $990 \pm 20.81$ & $955 \pm 25.31$ & $1013.28 \pm 33.63$ \\
\hline $\begin{array}{l}\text { Phenoloxidase(O.D. } \\
\text { units/g.b.wt) }\end{array}$ & $9.95 \pm 0.26$ & $5.96 \pm 0.2$ & $3.9 \pm 0.3$ & $4.33 \pm 0.4$ \\
\hline $\begin{array}{l}\text { N- acytel-glucceamin }(\mu \mathrm{g} \\
\text { NAGA/g.b.wt) }\end{array}$ & $344.67 \pm 8.44$ & $237.0 \pm 20.9$ & $221 \pm 11.6$ & $226.0 \pm 20.9$ \\
\hline $\begin{array}{c}\text { Chitnase } \\
\text { ( } \mu \mathrm{g} \text { NAGA } \times 10^{3} / \mathrm{min} / \mathrm{g} . \text { b.wt) }\end{array}$ & $1953.67 \pm 20.4$ & $2141 \pm 6.4$ & - & - \\
\hline $\begin{array}{c}\text { Aspartate } \\
\text { aminotransferase } \\
\text { (AST)(GOT) } \\
\text { (U x 10 } 1 \text { g.b.wt) }\end{array}$ & $246.0 \pm 4.6$ & $267.0 \pm 2.7$ & $215 \pm 20.8$ & $364.6 \pm 12.6$ \\
\hline $\begin{array}{c}\text { alanine aminotransferase } \\
\text { (ALT)GPT } \\
\text { (U x 10 } 10^{3} \text { g.b.wt) }\end{array}$ & $1616 \pm 3.4$ & $168.66 \pm 5.6$ & $698 \pm 31.6$ & $1237.36 \pm 13.5$ \\
\hline
\end{tabular}

The obtained data are in agreement with many authors tested different IGRs against Lepidopterous insects, e.g., P. gossypiella, Flint et al. (1978), Moawad and Khidr, (1982). Also, Spodoptera littoralis, Ismail, (1980); El-Deeb et al., (1991); Sokar, (1995); Shaurub et al., (1999) and Abdel-Aal, (2003).

Hewady et al., (2002) found that Neemazal disrupt larval and pupal development of pink bollworm, resulted malformations, reduction in longevity fecundity and fertility moth. Sammour et al., (2008) studied the effect of Chlorfluazuron and Leufenuron on S. littoralis, and indicated that this compound decrease adult emergence, longevity, fecundity and egg hatchability. Moursy and Salem (1995), Macro and Vinuela (1994) and Lyra et al., (1999) reported that IGRs caused morphological alternations of ovipositor and inhibition of the ovarian growth. Kellouche and Soltani (2006) found that Hexaflumuron decrease the longevity and fecundity of Callosobruchus maculates. Also, Al-Shannaf and Kandil (2005) determined the $\mathrm{LC}_{50}$ of spinosad for one and two days old eggs of Helicoverpa armigera as 2.56 and $1.31 \mathrm{ppm}$, respectively.

\section{Physiological aspects:}

The obtained results are in agreement with Assar et al., (2016) who studied the effect of Hexaflumuron and Teflubenzuron (IGR's) against the 4th instar larvae of Spodoptera littoralis on total carbohydrates, proteins, lipids, acetylcholinesterase, chitinase, phenoloxidase, carbohydrates hydrolyzing enzymes, non-specific esterases, phosphatases and transaminase enzymes, and reported that total proteins and lipids content were significantly decreased also, Hexaflumuron and Teflubenzuron caused an increase in total carbohydrates, moreover, the tested IGRs significantly increased the invertase activity but decreased the activity of trehalase and amylase in case of Teflubenzuron. The tested IGRs significantly decreased the activity of alkaline (AIP) phosphates. Teflubenzuron induced a significant increase 
on aspartate aminotransferase (AST) and alanine aminotransferase (ALT). Furthermore, Acelylcolinesterase (AchE) activity was significantly increased with Teflubenzuron while decreased with Hexaflumuron, as well as Phenoloxidase and Chitinase activity significantly increased.

Similar results were found by Mostafa, (1993) and Sokar, (1995) on S. littoralis. The protein pool of the haemolymph consider a source of protein synthesis for growth and development of the adult stage (Florkin and Jeanuiaux, 1964).

El-Sheikh et al., (2013) and Florkin and Jeanuiaux, (1964) reported that Teflubenzuron caused changes in trehalase on S. littoralis, the rapid decrease of glucose concentration of last larval instar of the cotton leafworm, was probably caused by high metabolic activity.

These results were also agree with the results which conducted by Abd El-Mageed and Shalaby, (2011) who reported that Teflubenzuron appeared reduction in acetylcholinesterase. El-Sheikh et al., (2013) stated that increase in chitinase activity and fluctuated changes were recorded when $S$. littoralis was exposed to Teflubenzuron.

\section{REFERENCES}

Abdel-Aal, A. E. (2003). Effect of some insect growth regulators on certain biological, biochemical and histological aspects of the cotton leafworm, Spodoptera littoralis (Boisd.). Ph.D. Thesis, Dep. of Entomol., Fac. of Sci. Cairo. Univ., Egypt. 119pp.

Abbott, W. S. (1925). A method of computing the effectiveness of an insecticide. J. of Econ. Entomol., 18: 265267.

Abd El-Mageed, A. E. and S.E. Shalaby (2011). Toxicity and biochemical impacts of some new insecticide mixtures on cotton leafworm Spodoptera littoralis (Boisd). Plant Protec. Sci., 47:166-175.

Al-Shannaf, H. M. H. and M. A. A. Kandil (2005). Effect of spinosad on some biological aspects of Helicoverpa armigera (Hub). Egypt. J. of Appl. Sci., 20(12B):699-705.

Anonymous. (1996). Pink bollworm management, new letter of the pink bollworm action committee, A Project of the Cotton Foundation pp: 3.

Assar, A.A.; M.M. Abo El-Mahasen; H.F. Dahi and H.S. Amin (2016). Biochemical effects of some insect growth regulators and bio insecticides against cotton leaf worm, Spodoptera littoralis (Boisd.) (Lepidoptera: Noctuidae).J. of Biosci. and Appl. Res., 2, (8) PP.587-594.

Bade, M. L. and A. Stinson (1981). Biochemistry of insect differentiation. A system for studying the mechanism of chitinase activity in vitro. Archs Biochem. Biophys.; 206: 213-221.

Barazani, A. (2001). Rimon, an IGR insecticide. Phytoparasitica, 29: 59-60.

Bradford, M. M. (1976). A rapid and sensitive method for the quatitation of microgram quantities of protein utilizing the principle of protein-dye binding. Anal. Biochem., 72: 248-254.

Crystal, M.M. and L.E. Lachance (1963). The modification of reproduction in insects treated with alkylating agents. Inhibition of ovarian growth and egg reproduction and hatchability. Biol. Bull., 25: 270-279.

El-Deeb, M. A.; F. E. Ghouneim and F. I. Helmy (1991). Potential use of juvenile hormone pyriproxyfen for the control of Spodoptera littoralis. 4th Arab Cong. Plant Protec., Cairo, Egypt: 7-13.

El-Sheikh, T. A.; H. S. Rafea; A. M. ElAasar, and S. H. Ali (2013). Biochemical studies of Bacillus thuringiensis var .kurstaki, Serratia marcescns and teflubenzurone on cotton leafworm, Spodoptera littoralis (Boisd.) (Lepidoptera: Noctuidae). Egypt. Acad. J. Biol. Sci., 5 (1):19-30.

Flint, H. M.; R. L. Smith; J. M. Noble; D. Shaw; A. B. Denilo and O. Khalid (1978). Laboratory test of diflubenzuron and 4 analogues against the pink bollworm and 
a field case test with diflubenzuron and El-949 for control of bollworm and cotton leaf perforator. J. Econ. Entomol., 71:616-619.

Florkin, M. and C. H. Jeanuiaux (1964). Haemolymph composition. In "Physiology of Insecta": (Edited by Rockstein, M.). Academic Press, New York \& London., (3): 109-152.

Gijswijt, M. J., D. H. Deul and B. J. DeJong (1979). Inhibition of chitin synthesis by benzoylphenylurea insecticides, III. Similarity in action in Pieres brassicae (L.) with polyxin D. Pestic. Biochem. Physiol., 12:84-94.

Gurr, G. M., W. G. Thwaite and H. I. Nicol (1999). Field evaluation of the effects of the insect growth regulator (tebufenozide) on entomophagous arthropods and pests of apples. Austr. J. Entomol., 38: 135-140.

Hammock, C. D. and G. B. Quistad (1981). Metabolism and mode of action of juvenile hormone, juvenoids and other insect growth regulators. In: "Progress in pesticide Biochemistry" (Hutson, D.H. and Roberts, T.R. eds.). John Wiley \& Sons Ltd., (1): 1-85.

Hewady, A. A. H.; M. A. Kandel; A. A. ElSayed and A. M. Rashad (2002). Biological and Biochemical effects of Neemazal T/S on Pink bollworm Pectinophora gossypiella (Saunders) (Lepidoptera: Gelechiidae). J. Egypt. Acad. Soc. Environ. Develop., 2(2): 5365.

Ishaaya, I. (1971). Observation on the phenoloxidase system in the armored scale Aonidiella aurantii and Chrysomphalus aonidum. Comp. Biochem .Physiol ., 39 B, 935-943.

Ishaaya, I. and E. Swirski (1976). Trehalase, invertase and amylase activities in the black scale Saissetia oleae, and their relation to host adaptability. J. Insect Physiol. 22: 1025-1029.

Ishaaya, I., A. R. Horowitz, L. Tirry and A. Barazani (2002). Novaluron (Rimon), a novel IGR-Mechanism, selectivity and importance in IPM programs. 54th Intern. Symp. on Crop Protec., Part II, Gent, Belgium, 67 (3): 617-626.

Ismail, I. E. (1980). Physiological studies on the effect of juvenile hormone analogues upon the cotton leafworm, Spodoptera littoralis (Boisd.). Ph.D. Thesis, Fac. Sci., Cairo Univ. Egypt.

Kandil, M.A.A., M.S. Salem and A.M. Adly (2013). Biological and biochemical changes in pink bollworm, Pectinophora gossypiella after treatment with Hexaflumuron and Chlorfluazuron. Annals of Agric. Sci. Moshtohor, 51 (4): 427- 432.

Kellouche, A. and Soltani N. (2006). Impact of Hexaflumuron, a chitin synthesis inhibitor on growth, development and reproductive performance of the progeny in Callosobruchus maculatus after adult treatments. Afric. J. of Agric. Res., 1 (3):57-64.

Knight, J.A., S. Anderson and J.M. Rawle (1972).Chemical basis of the sulfophospho-vanillin reaction for estimating total serum lipids. Clin. Chem., 18:199202.

Lyra, S. R. M., J. M. G. Ferraz and A. P. P. Silva (1999). Action of chitin synthesis inhibitor on reproduction of Spodoptera littoralis. Review Agric. Entomol., 87-95.

Marco, V. and E. Vinuela (1994). Effects of hexaflumuron on fecundity, fertility and longevity of Ephestia kuehniella Zeiler and Spodoptera exigua (Hubner). Med. Fac. Land bouwwUmv. Gent 59/2a.

Miyamoto, J., Y. Hirano, S. Takimoto and M. Hatakoshi (1993). Insect growth regulators for pest control, with emphasis on juvenile hormone analogs: Present status and future prospects. ASC. Symp. Ser., ACS, Washington, DC. 524: 144 168.

Moawad, G. M. and A. A. Khidr (1982). The influence of juvenile hormone the pink bollworm, Pectinophora gossypiella (Saund.). Agric. Res. Rev., 60:225-235.

Mostafa, S. A. (1993). Biochemical effect of some chemical compounds on 
Spodoptera littoralis. Ph.D. Thesis, Fac. Agric., Al-Azhar Univ., Egypt.

Moursy, E. B. and M. S. Salem (1995). Influence of benzoylphenylurea on the metabolism of proteinaceous content, glycogen and acid phosphatase as related to eggs and ovarian development in, Pectinophor agossypilla (Sound). 1st Int. Conf. of Pest Control, Mansoura. Egypt.

Nehad, M. El-Barkey, A. E. Amer and Mervet A. Kandeel (2009). Ovicidal Activity and Biological Effects of Radiant and Hexaflumuron against Eggs of Pink Bollworm, Pectinophora gossypiella (Lepidoptera: Gelechiidae) Egypt. Acad. J. biol. Sci., 2(1): $23-36$.

Prabhaker, N. and N. C. Toscano (2007).Toxicity of the insect growth regulators, buprofezin and pyriproxyfen, to the glassy-winged sharp shooter, Homalodis cacoagulata Say (Homoptera :Cicadellidae). Crop, Prot. 26:495-502.

Raslan, S. A. (2002). Preliminary report on initial and residual mortality of the natural product, spinosad, for controlling cotton leafworm egg masses. In: Egypt.2nd Inter. Conf., Plant Prot. Res. Inst., Cairo, Egypt, 1: 635-637.

Raubenheimer, D., K .P. Lee and S. J. Simpson (2005). Does Bertrand's rule apply to macro nutrients. Proceedings of the Royal Society (Series B), 272: 24292434.

Reitman, S. M. and S. Frankel (1957). A colorimetric method for determination of serum glutamic pyruvic transaminase. Am. J. Clin. Path., (28):56-63.

Sammour, E. A., M. A. Kandil and N. F. Abdel-Aziz (2008). The reproductive potential and Fate of chlorfluazuron and leufenuon against cotton leafworm, Spodoptera littoralis (Boisd). AmericanEurasian J. Agric\& Environ. Sci., 4 (1): 62-67.

Shaurub, E. H., S. A. Emara, N. Z. Zohdy and A. E. Abdel-Aal (1999). Effect of four insect growth regulators on the black cutworm, Agrotis ipsilon (Huft.) (Lepidoptera: Noctuidae). The 2nd Int. Conf. of Pest Control, Mansoura, Egypt, pp: 773-776.

Simpson, S. J., R. M. Sibly, K. P. Lee, S .T. Behmer and D. Raubenheimer (2004). Optimal foraging when regulating intake of multiple nutrients. Animal Behaviour, 68, 1299-1311.

Snedecor, G.W. (1952). Statistical methods $5^{\text {th }}$ Ed.lowa State Col.N.Y. Preparation of samples for biochemical assay.

Sokar, L. A. (1995). Possible alternative to classical insecticides in management program of Spodoptera littoralis (Bosid.). Ph.D. Thesis, Fac. Agric. Moshtohor, Zagazig Univ., Egypt.

Soltani, N., M. T. Besson and J. Delachambre (1984). Effects of diflubenzuron on the pupal-adult development of Tenebriomolitor (L.) (Coleoptera: Tenebrionidae): growth and development cuticle secretion, epidermal cell density, and DNA synthesis. Pestic. Biochem. Physiol., 21:256-264.

Thompson S N, R. A. Redak; and L W. Wang (2005). Host nutrition determines blood nutrient composition and mediates parasite development success: Manducasexta L. parasitized by Cotesia congregata (Say). J. of Exper. Biol., 208, 625-635.

Tunaz, H. and N. Uygun (2004). Insect growth regulators for insect pest control. Turk. J. Agric. Fore., 28: 337-387.

Waterhouse, D.F., R.H. Hockman and J.W. Mckellar (1961). An investigation of chitinase activity in cockroach and termite extracts. J. Insect physiol., 6:96112.

Zidan, Z.H., M. I. Abdel-Mageed, W.M. Watson and A.K. Sobeiha (1987). Ovicidal activity of certain mineral oils, organic insecticides and their mixtures against the cotton leafworm Spodoptera littoralis (Boisd.). Appl. Ent. Zool., 22: 241-247. 
Said, et al.,

التأثثرات الكيميائية و البيولوجية لمنظم النمو الحشرى تيفلوبينزيرون على دودة اللوز

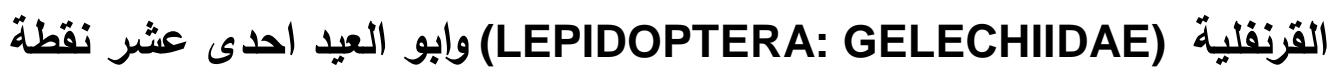
(COLEOPTERA: COCCINELLIDAE)

سعدية محمد سعيل(1)، احمد محمد عبد الرحيم(1)، ميرفت عبد السميع قنديل(2)

(1) قسم الحشرات الاقتصاديه والحيوان الزراعى - كلبة الزراعه- جامعة المنوفيه

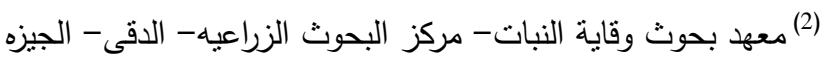

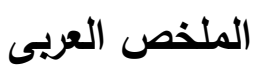

أجريت هذه الدراسه لمعرفة تأثنر منظم النو الحشرى تيفلوبينزيرون على كلا من نسبة حياة وتكاثر حشرة دودة اللوز القرنفليه وعلى العذارى والاطوار الكاملة للمفترس ابو العيد 11 نقطه. بالنسبه لدودة اللوز القرنفليه كانت قيم

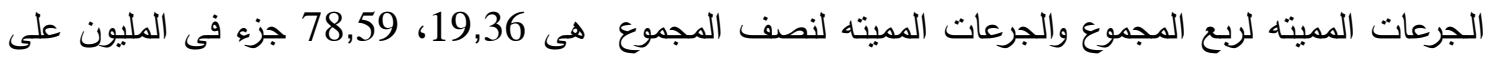
التوالى عند معاملة اليرقات حديثة الفقس بال تيفلوبينزيرون فى حين كانت قيمة الجرعه المميته لـ 90٪ من المجموع جرع

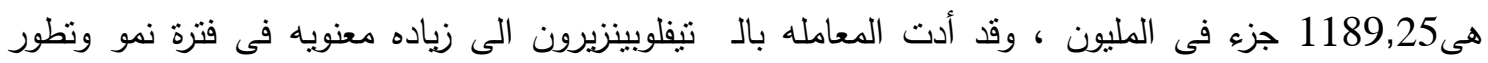

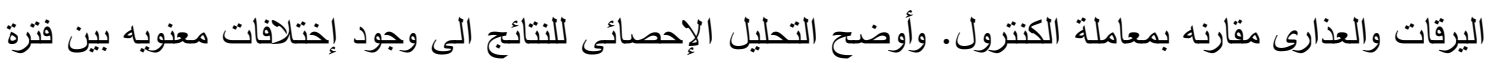

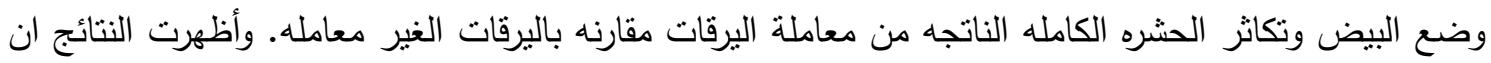
المعامله بالجرعه المميته لنصف المجموع بال تيفلوبينزيرون عند 78,59 جزء فى المليون أدى الى إنخفاض

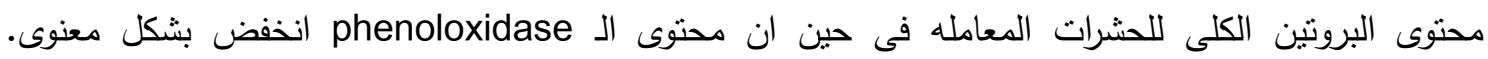
وأظهرت النتائج ان نشاط إنزيم الـ Chitinase زاد بشكل معنوى مسببا فثنل فى عملية التعذر ، وزاد نشاط إنزيم الـ transaminase بالنسبه لحشرة أبو العيد 11 نقطه كانت نسب الموت مختلفه لكلا من العذارى والحشرات الكامله بعد يوم الى

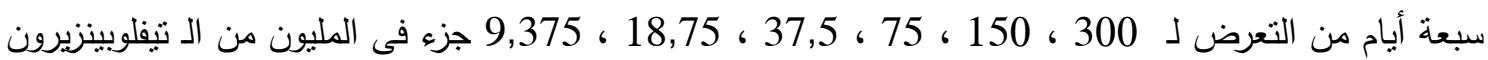

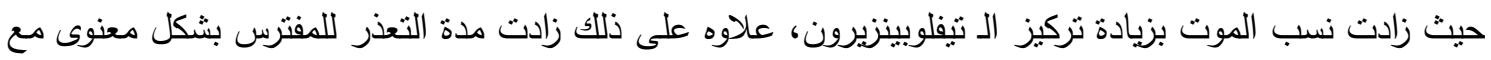
زيادة جرعة منظم النمو فى حين انخفضت طول فترة العمر والخصوبه للحشرات الكامله بشكل معنوى. انخفضت أيضا بشكل معنوى قيم المحتوى الكلى للبروتين وال phenoloxidase عندما عوملت العذارى وتغذت الحشرات الكامله بالجرعه القاتله لنصف المجموع من منظم النمو تيفلوبينزيرون. 
Biochemical and biological effects of insect growth regulator, teflubenzuron ... 